\title{
Archaeological Investigation Along the Route of U.S. 281, From Mulberry Avenue to Tuxedo Avenue in San Antonio
}

Clive Luke

Follow this and additional works at: https://scholarworks.sfasu.edu/ita

Part of the American Material Culture Commons, Archaeological Anthropology Commons, Environmental Studies Commons, Other American Studies Commons, Other Arts and Humanities Commons, Other History of Art, Architecture, and Archaeology Commons, and the United States History Commons

Tell us how this article helped you.

This Article is brought to you for free and open access by the Center for Regional Heritage Research at SFA ScholarWorks. It has been accepted for inclusion in Index of Texas Archaeology: Open Access Gray Literature from the Lone Star State by an authorized editor of SFA ScholarWorks. For more information, please contact cdsscholarworks@sfasu.edu. 


\section{Archaeological Investigation Along the Route of U.S. 281, From Mulberry Avenue to Tuxedo Avenue in San Antonio}

\section{Licensing Statement}

This is a work produced for the Texas Department of Transportation (TxDOT) by the report producer. TxDOT and the report producer jointly own all rights, title, and interest in and to all intellectual property developed under TXDOT's contract with the report producer. The report may be cited and brief passages from this publication may be reproduced without permission provided that credit is given to both TXDOT and the report producer. Permission to reprint an entire chapter, section, figures or tables must be obtained in advance from either the Supervisor of the Archeological Studies Branch, Environmental Affairs Division, Texas Department of Transportation, 125 East 11th Street, Austin, Texas, 78701 or from the report producer. 
ARCHAEOLOGICAL INVESTIGATION

ALONG THE ROUTE OF

U, S. 281, FROM MULBERRY AVENUE

TO TUXEDO AVENUE IN SAN ANTONIO

\author{
by \\ CLIVE LUKE
}

Texas Highway Department Publications in Archaeology: 1974 


\section{INTRODUCTION}

The route of impending U.S. 281 from Mulberry Avenue to Tuxedo Avenue in San Antonio traverses the valley of Olmos Creek. The creek originates in the southern edge of the Edwards Plateau between Leon Creek and Salado Creek, and flows in a southeasterly direction to its confluence with the San Antonio River. Near that confluence is a series of large fissure springs occurring along the fault zone. The topography of the drainage area varies from rolling to hill*, with the area under concern in this report being undeveloped and covered with brush (Corp of Engineers, US A rmy, 1972).

The Olmos Dam is a concrete gravity type, owned and operated by the City of San Antonio for flood protection of the city's business section. Its construction was prompted by the damage caused by a flood in 1921. Construction was started in 1925 and completed in 1926 ,

An area such as the Olmos Basin with its springs would have been attractive to aboriginal inhabitants. Consequently in compliance with Senate Bill 58 and the A ntiquities Code of Texas, the right-of-way of the North Expressway was surveyed to determine what archaeological sites would be encountered. After a thorough reconnaissance in early September 1974, it seemed that the proposed highway avoided those places which seemed most likely to have seen prehistoric encampments; however, three areas peripheral to or near known Indian sites were regarded worthy of testing. Accordingly, under Antiquities committee Permit No. 67, archaeological testing was conducted from 17 September to 9 October 1974. The following pages constitute the report of that investigation. 
41 BX 193 An Archaeological Investigation Within "Excavation Site B"

"Excavation Site B " is a material source area designated by the Texas Highway Department. It is bordered by Contour Drive, the San Antonio Gun Club, Basse Road, the Missouri-Pacific Railroad tracks, and the proposed right-of-way of the North Expressway. As a material source area, fill will be removed for use in construction of the North Expressway. Consequently, this area was included in the initial archaeological reconnaissance of the route of the proposed highway. Several pieces of flint collected during the initial exploration suggested the presence of a buried archaeological site. Accordingly, the designation, 41BX 193, was assigned and Antiquities Permit \#67 was obtained. Nine 5 feet $x 5$ feet test units were placed across the site.

The first eight test units were established randomly on a grid system projected onto the site. They were excavated in six inch levels usually to a depth of one foot. However, a unit at N1000/E1025 was taken to a depth of $1.5 \mathrm{feet}$, and the final unit (at N945/E 1465) went to a depth of only one-half foot since cultural material seemed to occur only in the upper few inches. The soil from these units was passed through a $1 / 4$ inch wire mesh screen

Of the few fragments of flint recovered during this excavation, only three demonstrated evidence of human workmanship. One biface fragment and one unifacially worked flake were found during the i nitialreconnaissance. The third specimen was a shattered fragment of what seemed to have been a bifacially worked flake. The later specimen was recovered from the uppermost level of the unit (N850/E1405). Every other piece of flint had been randomly broken or crushed rather than purposefully fractured.

C. D. Orchard pointed out an area from which he claims to have collected projectile points. Because the area was only a few hundred feet removed from the initial investigation of 41 BX 193 , the Iocationwas designated Area 2 of 41 BX 193. Orchard stated that the spot was formerly used as a football field by the Texas Military Institute. Upon examination of the area, two sewer lines were noted running through it. Also, in the vicinity of the sewer lines, a layer of gravel, apparently waste from laying the pipes, was encountered. One unit in Area 2 was dug to a depth of two feet. Because the moist clayey soil was impossible to screen, the unit was dug exclusively with trowels. In A rea 2, the dirt thrown up from the contractor's auger holes was examined but no evidence of aboriginal activity was found. Due to the heavy grass cover, the soil was turned over with shovels in several places but no evidence of prehistoric occupation was forthcoming. 
41 BX 193

Whatever site may have existed within the 1 imits of "Excavation Site B", it seems to have been obliterated by land moving operations in past years. The area is now thickly overgrown by mesquite, acacia, yucca, and an occasional oak. Past activities might have necessitated extensive clearing operations. Former use as a football field and also as a balloon training field would suggest that the area had been cleared and perhaps leveled. Furthermore, laying sewer lines would be added disruption at any site.

Although $i t$ is unlikely that the aboriginal inhabitants of Texas avoided "Excavation Site B", it seems likely that historic activity has obliterated the evidence of any such aboriginal occupation and therefore the area warrants no further investigation. 


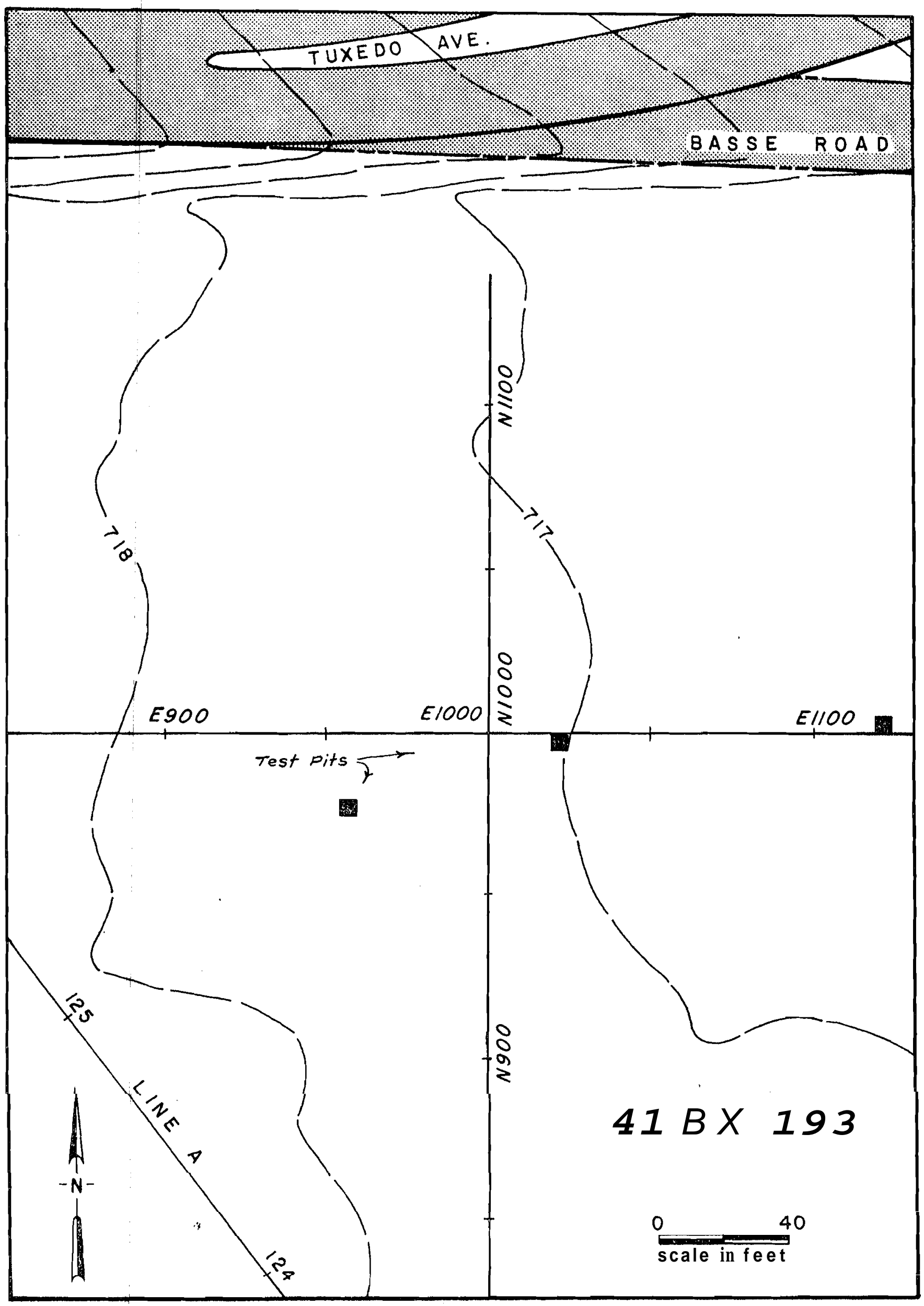

Fig. 1 


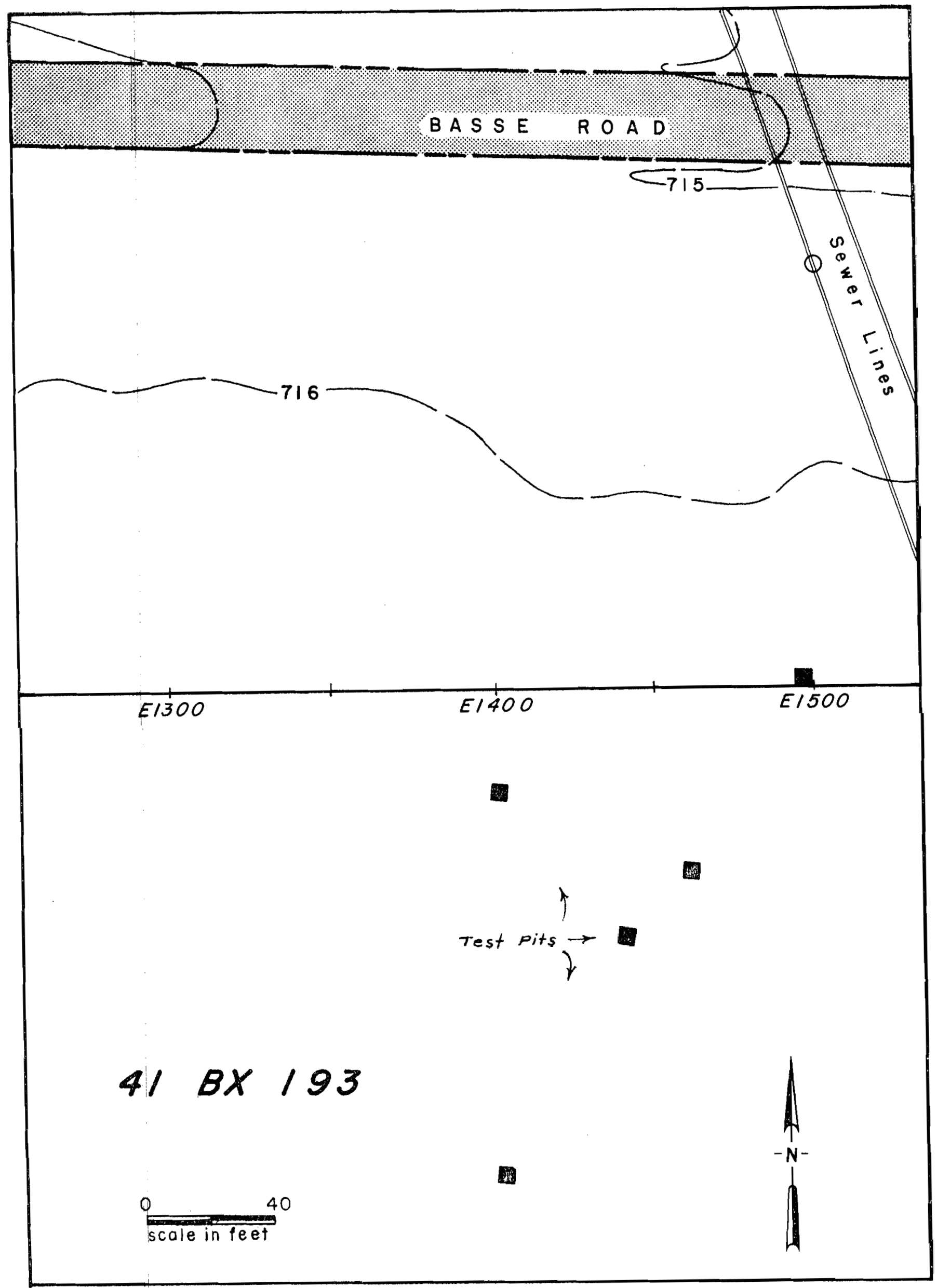

Fig 2 


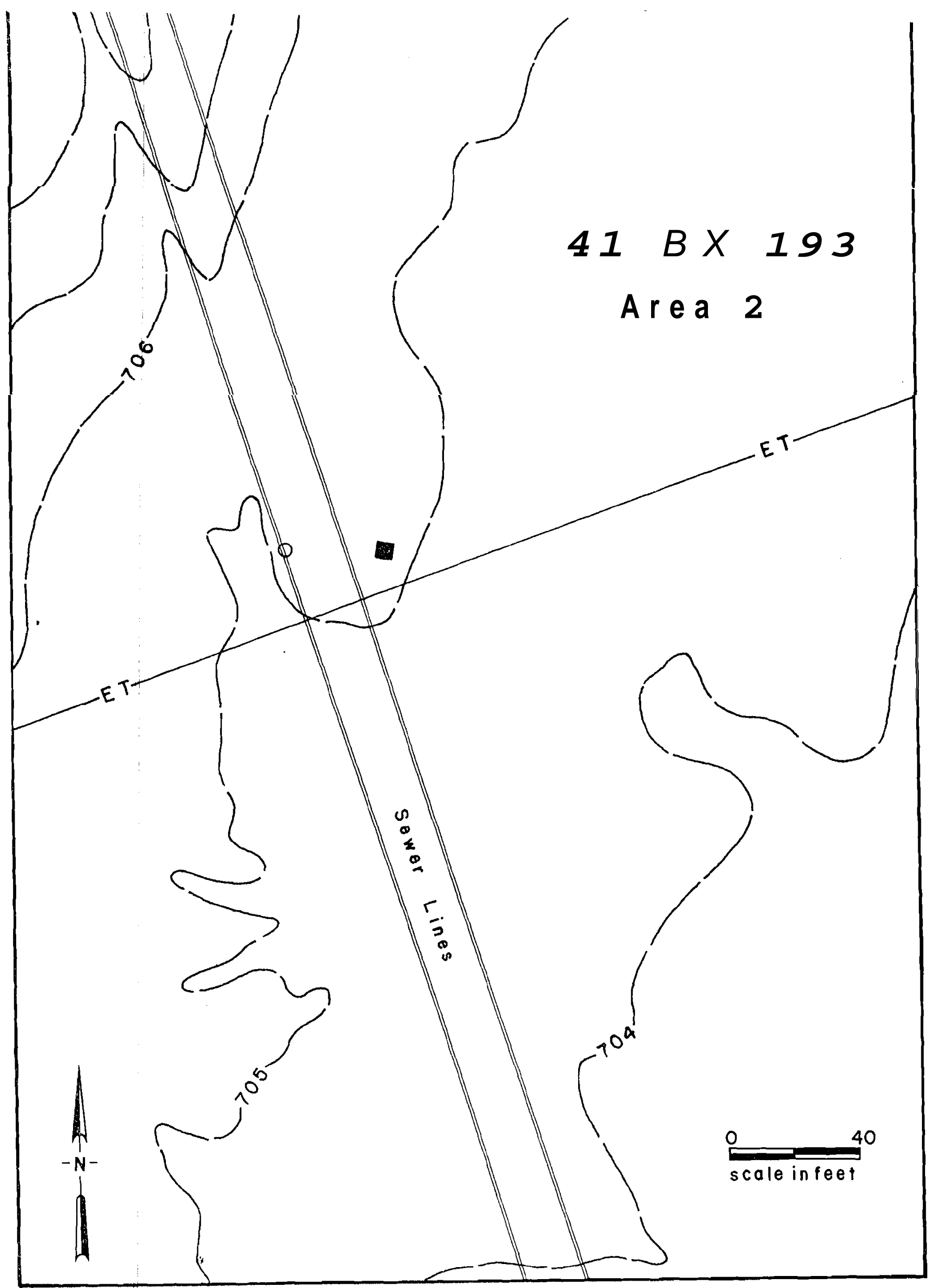

Fig. 3 
EXCAVATION PERIPHERAL TO 41 BX 24:

On the flood plain of the Olmos Creek, about 200 feet downstream from the dam, lies the archaeological site designated 41 BX 24 On the east side of the creek, a terrace remnant forms a small knoll, its height dominating the surrounding flood plain. On this terrace remnant, debris from prehistoric occupation is quite obvious.

Surface indications of aboriginal occupation seem to be confined predominantly to the higher ground of the flood plain; consequently, since there was no encroachment by the proposed highway, little expectation was had that the right-of-way of the North Expressway would in any way affect the archaeological site on the property owned by the Sisters of Charity of the Incarnate Word. However, to verify that expectation, Texas Highway Department Archaeologists directed the efforts of volunteers from Incarnate Word College in digging several test units.

Seven test units were excavated along the east right-of-way line between project Stations \#222 and \#227. The area is now thickly overgrown with laurel, mesquite, acacia, winged elm, oak, some persimmon, pecan, chinaberry, and large mature prickly pear. Each 5 foot $x$ foot unit was dug in six inch levels, and the soil was passed through $1 / 4$ inch wire mesh screen, Invariably, at a depth of about five inches, limestone gravel mixed with the clay loam indicated the top of the decomposing bedrock. In those units excavated to a second level, the small limestone fragments gave way to larger fragments of weathered bedrock. No cultural material came from any depth deeper than the initial occurrence of gravel.

The sparse return of cultural material was limited to lithic artifacts. Only two biface fragments were found, both from the first level. One fragment, from Unit 7, was the distal end exhibiting fine retouch flaking scars. The other, from Unit 1, was the proximal end of a triangular biface but showed no evidence of fine retouch flaking. Unit 1 also yielded eight additional flakes. The second unit produced one heavy percussion flake. In the third unit three flint flakes were found, one having been worn and fractured from utilization on two edges. The fourth unit produced five flint flakes and a core having a prepared striking platform. The fifth unit had three flint flakes, and the sixth unit had one flake. In addition to the biface fragment, the seventh unit also yielded one small piece of flint which 
41 BX 24

did not seem to have been produced by any purposeful flaking. The sparse artifact return does indeed indicate that 41 BX 24 in no way extends into the proposed right-of-way of the North expressway. The proposed highway passes through an area away from the main activity area and therefore warrants no further investigation. 


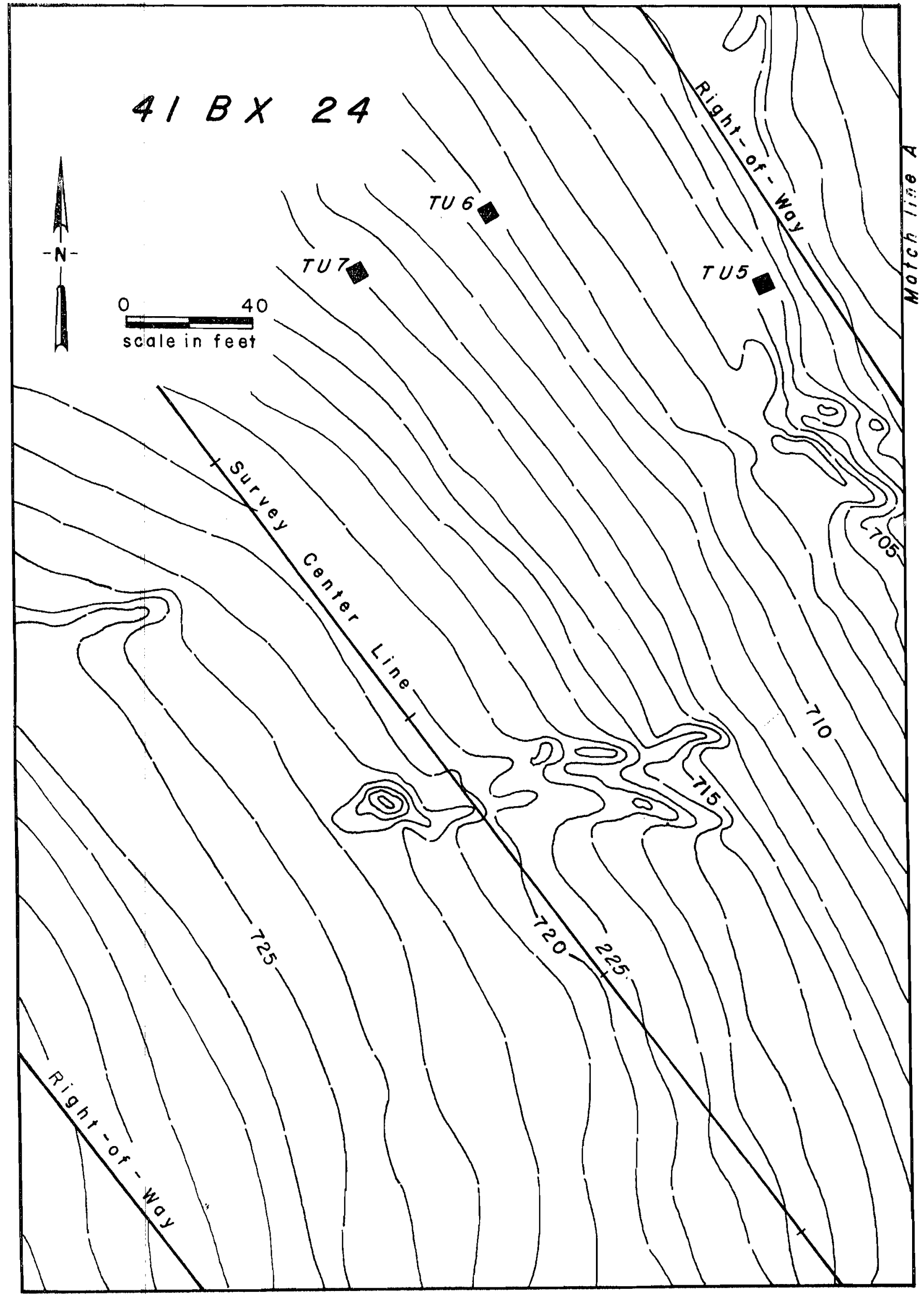




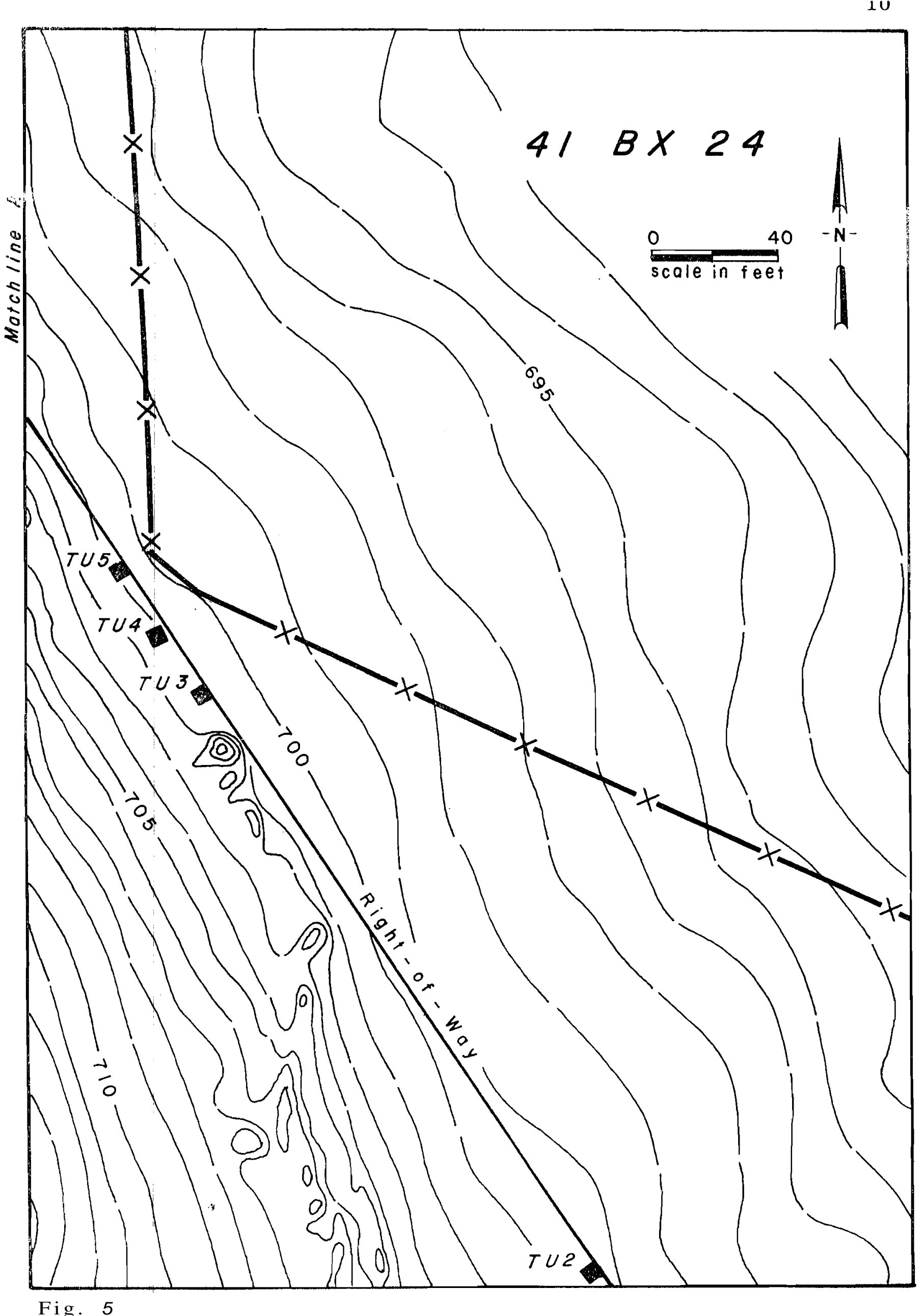


EXCAVATION NORTH OF OLMOS DAM PERIPHERAL TO 41 BX 1:

In the area immediately northwest of the Olmos Dam, some small quantity of flint debitage was observed during the initial survey by the Texas Highway Department.

In the autumn and winter of 1921-22, C. D. Orchard and J. H. McLellan, local amateur archaeologists, collected a number of projectile points from this area and a number seem to date from the Paleo Indian Stage (Orchard and Campbell, 1954). Other private dollections in San Antonio also contain many artifacts from this same area. Because the records at the Texas Archeological Research Laboratory at Balcones Research Center indicated that $41 \mathrm{BX} 1$ was approximately in this vicinity, any testing done in the right-of-way of U.S. 281 between the Olmos Dam north to Devine Road was considered to be in 41BX1. Consequently, several Pest units were dug to determine the nature of the site within the right-of-way.

Expectations for the discovery and recovery of any artifact concentration or culturally related feature of the prehistoric period ware minimal. Certainly clearing during the construction of the dam would have been disruptive to any archaeological site. Furthermore, concrete slabs, still visible, which formed a complex of small buildings associated with a golf driving range, indicated additional disturbance. Extensive sheet erosion would also be expected since this area lies in the Olmos Flood Basin. Apart from the vicinity of the concrete slabs, the site was heavily overgrown with laurel, acacia, winged el ms, medquite, and large mature prickly pear.

Nine test units were dug within the right-of-way between Olmos Dam and project Station \#244. These ranged in depth from two and one-half feet to one foot. Each unit was five feet $x$ five feet and was dug in arbitrary six inch levels. The soil from a 11 units was passed through $1 / 4$ inch wire mesh screen. Every unit was taken down to the bedrock.

An access road from Devine Road to the golf driving range effectively divided the excavation into two areas, with the concrete slabs lying in the area south of the road. Four units were dug in this area. As noted above, extensive disturbance to the sitewas expected. Nevertheless, because of its proximity to the area where C. D. Orchard collected projectile points of the Paleo Indian Stage, testing seemed desirable.

Several flint artifacts were recovered as well as some quantity of lithic debitage. Among the artifacts were three distal bifaee fragments. Two were thick and exhibited very little 
evidence of fine retouch. The third was much thinner and indicated fine retouch probably done by pressure flaking. Four blade tools were also found. These were flakes having a prismatic cross section and at least one edge worn by utilization. Unit 1 yielded a large, flat percussion flake, retaining cortex on one flat side and having steep unifacial retouching on the end opposite the striking platform.

The area north of the access road seemed to be less disturbed, being farther from the dam and probably not involved with the golf driving range. Five test units were dug here. Several artifacts came from this part of the site. Besides a large quantity of waste material from lithic manufacturing processes, several biface fragments were recovered. Six of these were distal fragments. Although they tended to exhibit some fine retouch flaking scars, they did not seem to be finished product\$. One s mall biface was recovered from the upper level of Unit 6. The artifact could be classified as Granbury type, joshua variety (Jelks, 1962). Finally, seven proximal fragments were recovered. Their degree of completion tended to be about the same as that of the distal fragments. One Perdiz arrowpoint was found on the surface.

Apparently this area, and probably the first area, were the former sites of lithic manufacture. Flint recovered from these unitstended to be waste material from the initial stages of production: expended cores, shattered and broken but unfinished bifacially worked flakes, and miscellaneous debitage. Although some probable pressure flakes were recovered, the waste material suggests that the final shapeing of artifacts may have taken place elsewhere.

Because of the nature of our findings and since our excavations and the proposed right-of-way is not in the main area of the site, further investigation beyond exploratory testing was not performed nor warranted. 


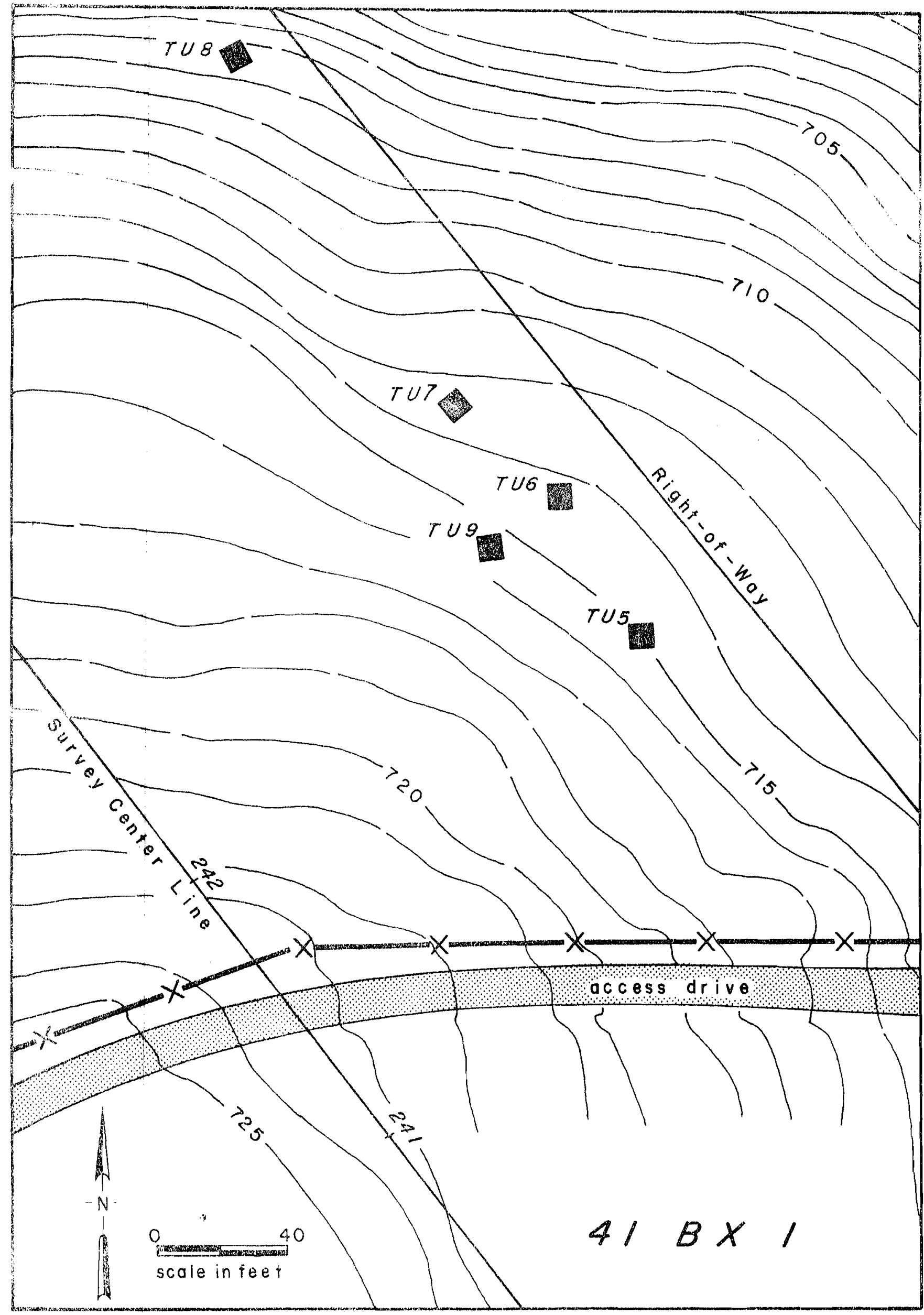

Fig. 6 


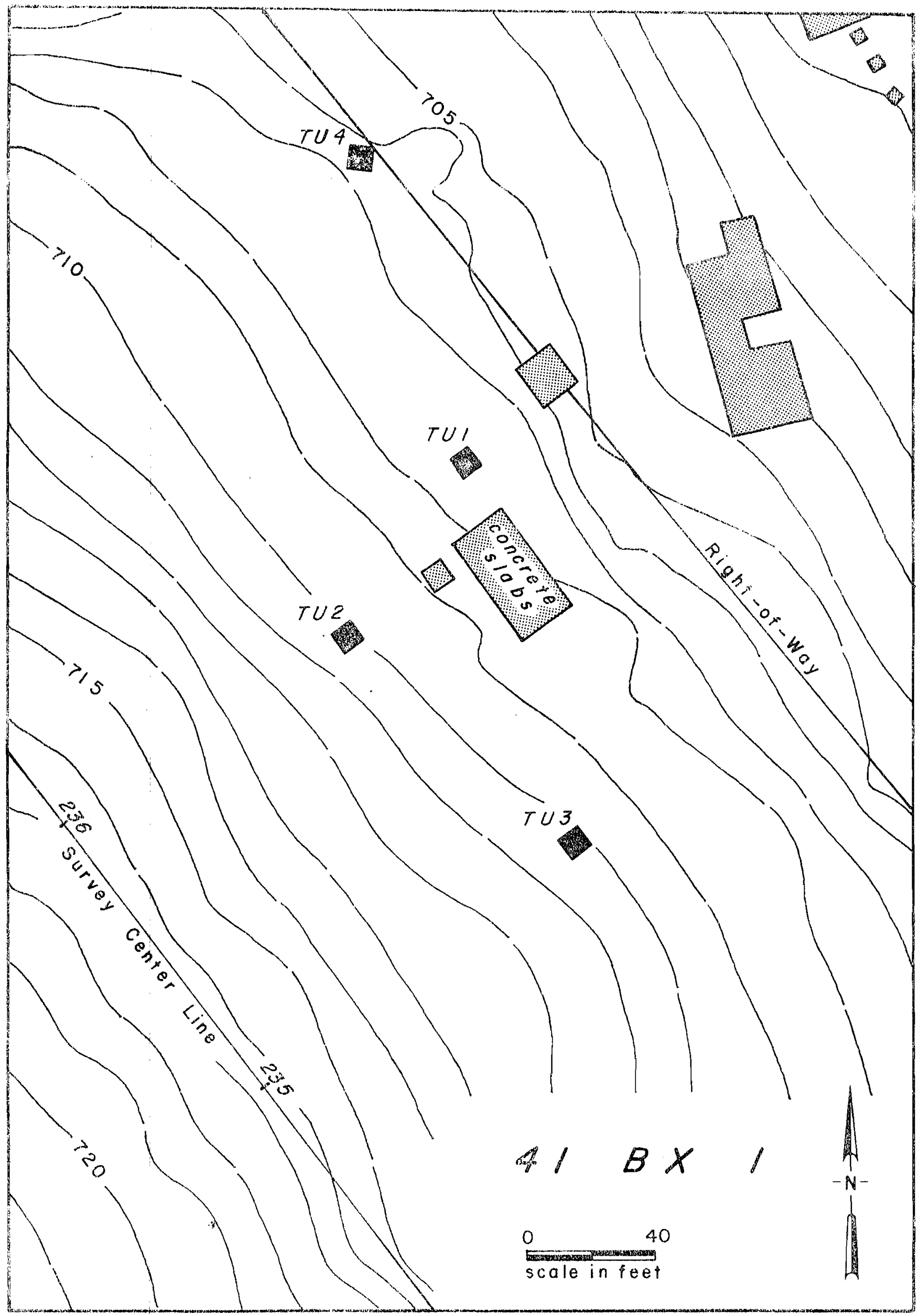

Fig. 7 


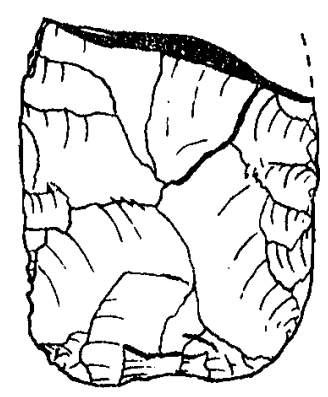

A

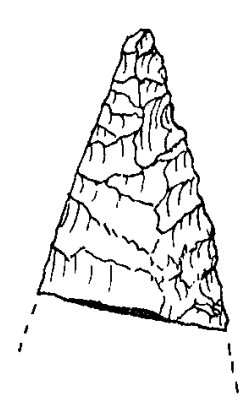

B

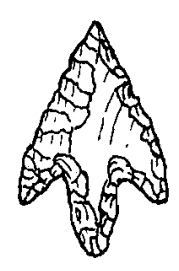

$\mathrm{C}$

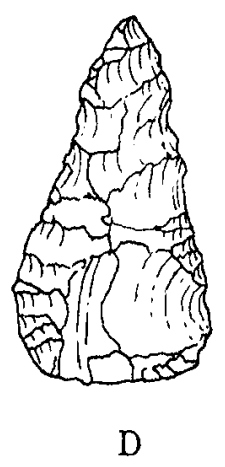

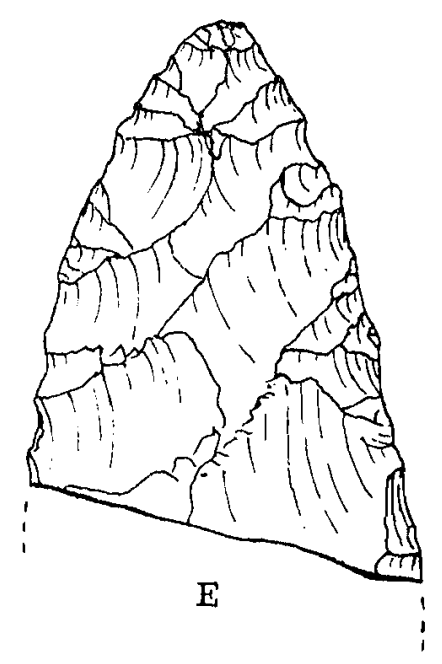
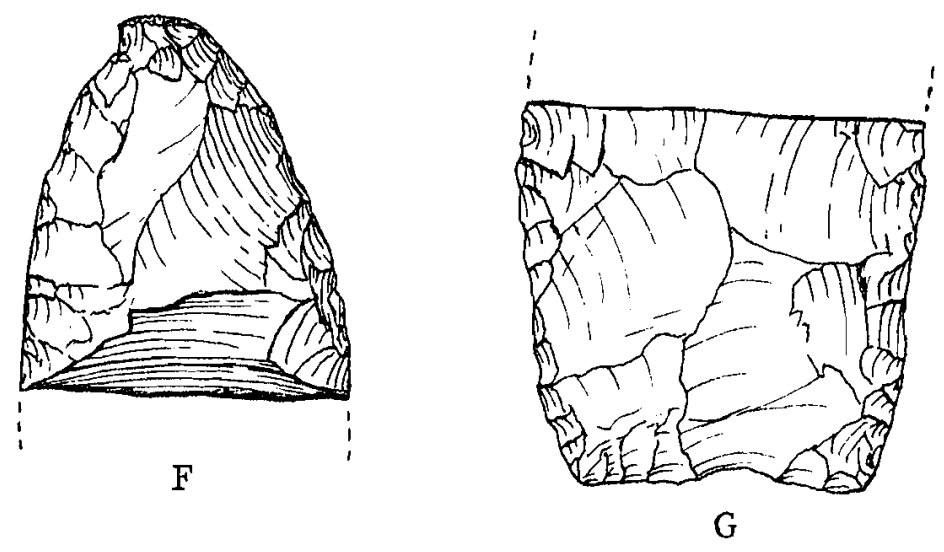

Fig. 8. A: 41 BX 24; Biface, proximal fragment; Test Unit 1 , Level 1 .

B: 41 BX 24; Biface, distal fragment; Test Unit 7 , Level 1 .

C: 41 BX 1; Perdiz Point; Surface find.

D: 41 BX 1; Granbury Point; Test Unit 6 , Level 1.

E: 41 BX 1; Biface, distal fragment; Test Unit 6 ,

Level 2 .

F: 41 BX 1; Biface, distal fragment; Test Unit 4,

G: 41 BX 1; Biface, proximal f agment; Test Unit 7, Level 1 . 


\section{References}

Jelks, Edqard B.

1962

The Kyle Site: A Stratified Central Texas Aspect Site in Hill County, Texas. Archeological Series, No. 5, Department of Anthropology, the University of Texas.

Orchard, C. D. and T. N. Campbell

1954 Evidences of Early Man from the Vicinity of San Antonio, Texas. The Texas Journal of Science, Vol. vi, No. 4, pp. 454-465. 